\title{
New species of Penzigomyces, Sporidesmium and Stanjehughesia from plant debris in Spain
}

Julio Mena-Portales ${ }^{1}$, Margarita Hernández-Restrepo*2,3, Josep Guarro ${ }^{4}$, David W. Minter ${ }^{5}$ and Josepa Gené ${ }^{4}$

\footnotetext{
${ }^{1}$ Instituto de Ecología y Sistemática, Ministerio de Ciencia, Tecnología y Medio Ambiente, La Habana 19 C.P. 11900, Cuba.

${ }^{2}$ CBS-KNAW Fungal Biodiversity Centre, Uppsalalaan 8, 3584 CT Utrecht, The Netherlands. * Corresponding author: m.hernandez@cbs.knaw.nl.

${ }^{3}$ Department of Microbiology and Plant Pathology, Forestry and Agricultural Biotechnology Institute (FABI), University of Pretoria, Pretoria 0002, South Africa.

${ }^{4}$ Unitat de Micologia, Institut d'Investigació Sanitària Pere Virgili (IISPV), Universitat Rovira i Virgili, 43201 Reus, Spain.
}

${ }^{5}$ CABI Bioscience. Bakeham Lane, Egham, Surrey, TW20 9TY, UK

\begin{abstract}
Four new species of Sporidesmium complex collected on plant debris in different protected areas of the Iberian Peninsula are described and illustrated. Penzigomyces basiacutus is characterized by its obclavate to rostrate conidia with a narrowly obconictruncate basal cell and verruculose apical cell. Sporidesmium corniculatum is distinguished from other species of the genus by its occasional furcate and only transversely septate conidia and Sporidesmium tunicatum by its obclavate to rostrate, verrucose conidia with an apical mucilaginous sheath tunica. Stanjehughesia obclavorostrata is distinguished by its obclavate to rostrate conidia with the basal cell sometimes darker than the rest.
\end{abstract}

Key words: anamorphic fungi, Hyphomycetes, Spain, taxonomy. 


\section{Introduction}

The Sporidesmium complex is a large anamorphic group of dematiaceous fungi with nearly 250 species mostly colonizing branches, trunks and dead leaves of many plants. Sporidesmium was established by Link in 1809 , but the traditional concept of the genus is based on the Ellis's description of S. ehrenbergii (Ellis, 1958, 1971). Sporidesmium has been considered a heterogeneous genus (Sutton \& Hodges, 1979; Hughes, 1979) and repeatedly revised (Kirk 1982, Subramanian 1992, Hernández-Gutiérrez \& Sutton 1997, Shoemaker \& Hambleton 2001).

Following the criteria of Hughes (1979), Kirk (1982) established the genus Sporidesmiella P.M.Kirk for species with few septa and cuneate to obovoid conidia. Subramanian (1992) segregated a large number of Sporidesmium species, according to the type of conidiophore proliferation and conidial septation, into the genera Ellisembia Subram., Penzigomyces Subram., Polydesmus Mont., Repetophragma Subram., Sporidesmiella P.M.Kirk, Sporidesmium Link, and Stanjehughesia Subram. A few other species were transferred to other genera such as Acarocybellina Subram., Gangliophora Subram., Hemicorynesporella Subram., and Janetia M.B.Ellis. Sporidesmium densum (Sacc. \& Roum.) Mason \& S.Hughes was considered congeneric with Polydesmus elegans Durieu \& Mont., the type species of the genus, which was not accepted by Hernández-Gutiérrez \& Sutton (1997) who proposed the genus Imimyces A.Hern. \& Sutton for Sp. densum and other similar species. In addition, these authors erected the genus Linkosia A.Hern. \& Sutton to accommodate Sp. coccothrinacis A.Hern. \& J.Mena as the type, and proposed seven new combinations. Linkosia was characterized by distoseptate conidia formed on conidiogenous cells, which arise directly from the fertile hyphae. Shoemaker \& Hambleton (2001) did not accept Imimyces because they considered that the specimen designated as the type species was a Polydesmus and therefore proposed the genus Imycles for the rest of Imimyces species defined by Hernández-Gutiérrez \& Sutton (1997). However, Réblová (1999) questioned the validity 
of these genera because she considered that their diagnostic characters on the natural substrate differed from those in culture, and also due to the lack of correlation with anamorphteleomorph connections previously established. Wu \& Zhuang (2005) considered the distinction between Penzigomyces-Sporidesmium and Ellisembia-Imycles very difficult when based on conidiophore proliferation and conidiogenous cell morphology, and preferred to simplify the taxonomic system considering Imycles and Penzigomyces as synonyms of Ellisembia and Sporidesmium, respectively. Shenoy et al. (2006), using molecular techniques, demonstrated that most of these segregate anamorphic genera were phylogenetically heterogeneous, but Seifert et al. (2011) accepted all segregated genera of Sporidesmium sensu lato as morphologically different groups that were useful for identification purposes.

During a survey of anamorphic fungi on plant debris in different protected areas of the Iberian Peninsula four interesting species morphologically compatible with the Sporidesmium complex were collected. Based on the conidial morphology, size and pigmentation, these species are proposed here as new.

\section{Materials and Methods}

Samples of plant material were processed using the methodology described by CastañedaRuiz (2005). Fungal specimens were studied and illustrated following Hernández-Restrepo et al. (2012). After testing different media and culture conditions, attempts to establish monoconidial cultures of the species described, failed and, therefore, only dried material could be preserved. Specimens are deposited in the herbarium of Centraalbureau voor Schimmelcultures, Utrecht, The Netherlands (CBS) and Facultat de Medicina i Ciències de la Salut, Reus, Spain (FMR).

\section{Taxonomy}

Penzigomyces basiacutus Hern.-Restr., J.Mena, Gené \& Guarro, sp. nov. Figs 1-2 MYCOBANK No: MB 814910 


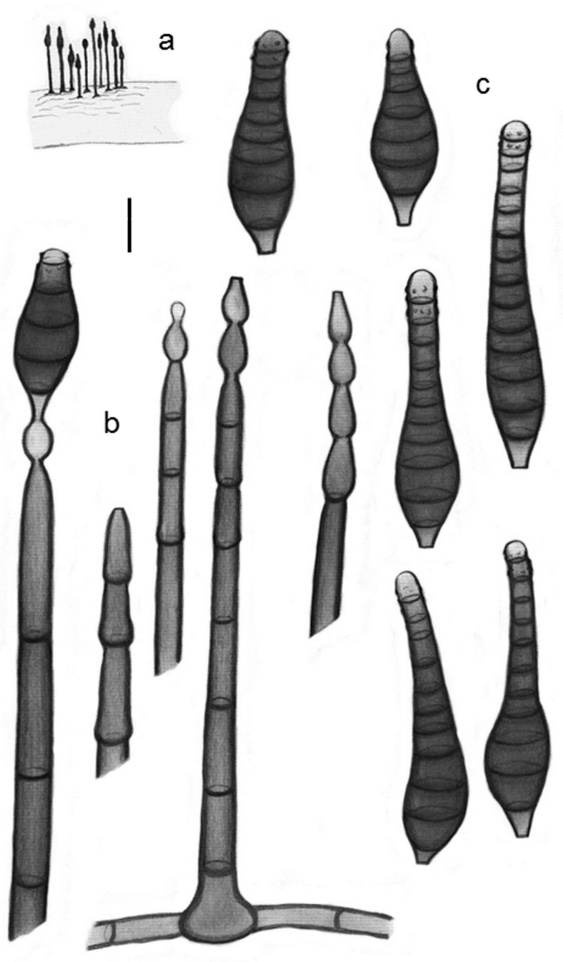

Fig. 1. Penzigomyces basiacutus. a. Habit. b. Conidiophores. c. Conidia. Scale bar $=10 \mu \mathrm{m}$. 
ETYMOLOGY: Referring to the narrowly obconic-truncate basal cell of conidia.

DESCRIPTION: Colonies effuse, black, hairy. Mycelium partly immersed in the substrate, hyphae pale brown, septate, branched, 1.5-2.5 um wide. Conidiophores macronematous, mononematous, solitary, simple, cylindrical, straight, smooth, septate, dark brown, up to 216 $\mu \mathrm{m}$ long, 5-7.5 $\mu \mathrm{m}$ wide, 7.5-17.5 $\mu \mathrm{m}$ at the bulbous base, 2.5-4 $\mu \mathrm{m}$ at the apex. Conidiogenous cells monoblastic, terminal, lageniform, smooth-walled, brown, 6-12 $\times 4.5-$ $5.5 \mu \mathrm{m}$, with up to seven lageniform percurrent proliferations. Conidia apical, solitary, dry, 315-septate, obclavate to rostrate, $28-73 \times 8.5-12.5 \mu \mathrm{m}, 4.5-5.5 \mu \mathrm{m}$ wide at the rostrate apex, 1.5-2.5 $\mu \mathrm{m}$ wide at the acute base, brown to dark brown, becoming pale brown toward the apex, basal cell narrowly obconic-truncate, pale to mid- brown, slightly verruculose at the apex. Sexual morph unknown.

SPECIMEN EXAMINED: SPAIN, Aragón, National Park of Ordesa y Monte Perdido. On dead wood. Jun. 2009. M.Hernández-Restrepo, J.Mena \& J.Cano (holotype CBS H-21044, isotype FMR 11158).

The genus Penzigomyces was established by Subramanian (1992) for former Sporidesmium species characterized by doliiform, lageniform or nodose percurrent conidiogenous cell proliferations and euseptate conidia. However, Wu \& Zhuang (2005) considered Penzigomyces a synonym of Sporidesmium. Seifert et al. (2011) provisionally recognized all genera segregated from Sporidesmium on the basis of conidiogenous cell morphology and proliferation and conidial septation.

Penzigomyces basiacutus can be distinguished by its obclavate conidia with a verruculose rostrum and a truncate base with a terminal narrowly obconic cell. The conidia somewhat resemble those of P. australiensis (M.B.Ellis) Subram., P. nodipes (Penz. \& Sacc.) Subram. and P. uapacae (M.B.Ellis) Subram. However, in P. australiensis the conidia are smooth, 7-9-septate and measure 40-65 × 11-16 $\mu \mathrm{m}$ (Ellis 1976). Wu \& Zhuang (2005) widened its concept by including a Chinese specimen with conidia measuring 42-80 × 10-13 
$\mu \mathrm{m},(1.5-3 \mu \mathrm{m}$ at the rounded apex and $3-5 \mu \mathrm{m}$ at the conico-truncate base) and 9-13 septa. In $P$. nodipes the conidia are smooth-walled, 11-14-septate, sometimes constricted at the septa, and measure 36-67 $\times 6.5-8 \mu \mathrm{m},(1.5-4 \mu \mathrm{m}$ wide below the acute apex and 2.5-4 $\mu \mathrm{m}$ at the base); in addition this species is mainly found on palms and orchids in tropical areas (Ellis 1976, Wu \& Zhuang 2005). The conidia of P. uapacae are 5-8-septate, pale to mid brown and smooth-walled and measure 50-80 $\times 7-10 \mu \mathrm{m}$, tapering to 3-4 $\mu \mathrm{m}$ wide near the apex and 3$4 \mu \mathrm{m}$ wide at the base (Ellis 1958, 1976).

Sporidesmium corniculatum J.Mena, Hern.-Restr., Gené \& Guarro, sp. nov. Figs 3-4

\section{MyCoBANK No.: MB 814911}

ETYMOLOGY: referring to the occasional presence of furcate conidia.

DESCRIPTION: Colonies effuse, black, hairy. Mycelium partly immersed in the substratum, hyphae pale brown, septate, branched, 1.5-2 $\mu \mathrm{m}$ wide. Conidiophores macronematous, mononematous, solitary, simple, cylindrical, straight, septate, dark brown, smooth, 45-70 $\mu \mathrm{m}$ long, 5-7 $\mu \mathrm{m}$ wide, $7.5-8 \mu \mathrm{m}$ at the base, 3.5-5 $\mu \mathrm{m}$ at the apex. Conidiogenous cells monoblastic, integrated, terminal, smooth-walled, brown, 5-10 $\times 5 \mu \mathrm{m}$. Conidia apical, solitary, dry, 13-26-septate, obclavate to rostrate, sometimes furcate with two arms, 60-137.5 $\times 10-12.5 \mu \mathrm{m}, 3-5 \mu \mathrm{m}$ wide at the base, $4-8.5 \mu \mathrm{m}$ at the apex, mid- to dark brown, remaining pale brown towards the apex, smooth-walled; arms 5-17-septate, 25-92.5 × 6-9 $\mu \mathrm{m}$. Sexual morph unknown.

SPECIMEN EXAmined: SPAIN, Aragon, Natural Park Valles Occidentales. On bark. Mar. 2012. M.Hernández-Restrepo \& J.Capilla (holotype CBS H-21046, isotype FMR 12431).

The occasional presence of branched conidia and several percurrent proliferations could justify the inclusion of this species in other genera such as Actinocladium Ehrenb., Ceratosporella Höhn. or Triposporium Corda. The conidiogenesis of the members of these genera is similar to that of the Sporidesmium complex. However, the low frequency of furcate 


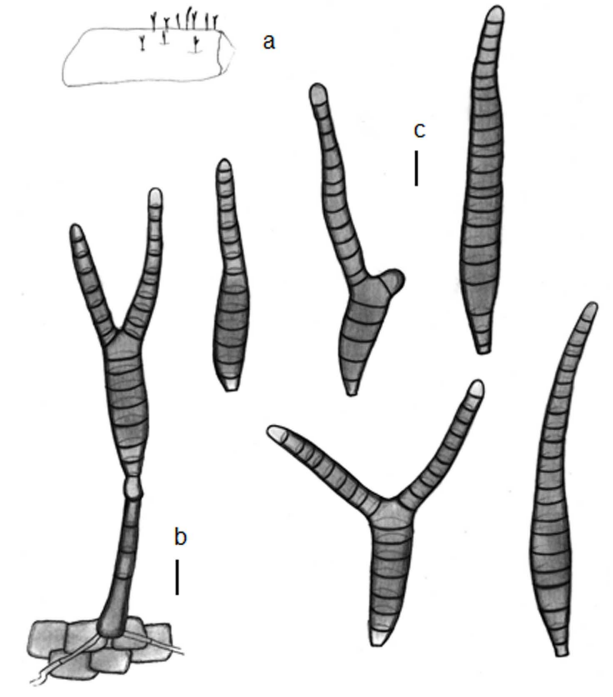

Fig. 3. Sporidesmium corniculatum. a. Habit. b. Conidiophore. c. Conidia. Scale bar $=10 \mu \mathrm{m}$.

8 
conidia observed in the Spanish specimen was the reason for including our isolate in Sporidesmium sensu Subramanian (1992).

The only species of Sporidesmium having typically furcate conidia is $\mathrm{Sp}$. taiwanense Matsushima (1983), but in this species the conidiophores are 0-2-septate, highly variable in length $(6-50 \mu \mathrm{m})$, the conidiogenous cells are determinate, and in the conidia, septa are constricted, sometimes oblique and rarely longitudinal, and the basal cell is obconic, pedicellate and brown. Wu \& Zhang (2005) suggested that Sp. taiwanense was better accommodated in Stanjehughesia on the basis of its euseptate and clavate conidia on discrete conidiogenous cells. However, a new combination was not established since the authors did not study the type material.

Ellisembia karadkensis Rajeshkumar \& SK Singh has been recently described with simple or branched conidia (Rajeshkumar et al. 2012); however, they are distoseptate, a character used by Subramanian (1992) to segregate Ellisembia from Sporidesmium. Other characters that distinguish E. karadkensis from Sp. corniculatum are that the furcate conidia are longer (190-250 $\mu \mathrm{m}$ long), narrower below the apex (2-2.7 $\mu \mathrm{m}$ wide) and have 10-35 distosepta.

Sporidesmium tunicatum M. Hern.-Restr., J. Mena, Gené \& Guarro sp. nov. Fig. 5-6

\section{MYCOBANK No.: MB 814912}

ETYMOLOGY: referring to the tunica, a mucilaginous sheath surrounding the conidial apex.

DESCRIPTION: Colonies effuse, black, hairy. Mycelium partly immersed, hyphae pale brown, septate, branched, 1.5-3 $\mu \mathrm{m}$ wide. Conidiophores macronematous, mononematous, solitary, simple, cylindrical, straight, septate, dark brown, smooth, 110-180 $\mu \mathrm{m}$ long, 6-7.5 $\mu \mathrm{m}$ wide, 8.5-12.5 $\mu \mathrm{m}$ at the base, $4-5 \mu \mathrm{m}$ at the apex, proliferation $0-1$, percurrent. Conidiogenous cells monoblastic, integrated, terminal, smooth-walled, brown, 19-25 × 5-6 $\mu \mathrm{m}$. Conidia apical, solitary, dry, 6-10 (mostly 8)-septate, obclavate, sometimes rostrate, 43-75 × 9-13 $\mu \mathrm{m}, 3-5 \mu \mathrm{m}$ wide at the base, $2.5-3.5(-5) \mu \mathrm{m}$ at the apex, dark olivaceous brown, becoming 


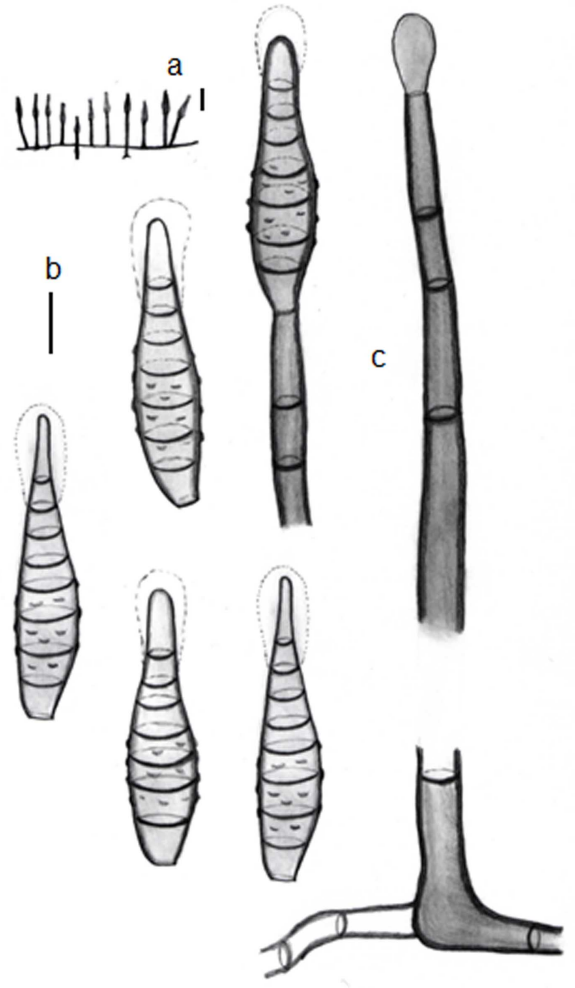

Fig. 5. Sporidesmium tunicatum. a. Habit. b. Conidia. c. Conidiophores. Scale bar $=10 \mu \mathrm{m}$. 
pale brown towards the apex, verrucose at the central cells, apical tunica $9-15 \times 10-30 \mu \mathrm{m}$. Sexual morph unknown.

SPECIMEN EXAMINED: SPAIN, Galicia, Natural Park As Fragas do Eume. On dead wood. May 2010. M.Hernández-Restrepo, J.Mena \& J.Guarro (holotype CBS H-21045, isotype FMR 11243).

Sporidesmium tunicatum differs from congeneric species (Ellis, 1958, 1971, 1976; Matsushima, 1971, 1975; Wu \& Zhuang, 2005) by the unique combination of the sometimes rostrate, usually 8-septate, verrucose conidia with an apical mucilaginous sheath. Sporidemium hainanense W.P.Wu is the most similar species, but its conidia are smooth and shorter (40-50 $\mu \mathrm{m})$ (Wu \& Zhuang, 2005).

Stanjehughesia obclavorostrata J.Mena, M.Hern.-Restr., Gené \& Guarro, sp. nov. Figs 7-8

\section{MYCOBANK No.: MB 814913}

ETYMOLOGY: referring to the conidial morphology.

DESCRIPTION: Colonies on natural substrate effuse, black. Mycelium partly immersed, hyphae branched, septate, subhyaline to pale brown, 1.5-3.5 $\mu \mathrm{m}$ wide. Conidiophores reduced to a single conidiogenous cell. Conidiogenous cells monoblastic, determinate, ampulliform or lageniform, erect, straight or flexuous, thick and smooth-walled, mostly solitary, sometimes caespitose, brown to dark brown, 13.5-20(-24) $\mu \mathrm{m}$ long, 7.5-12.5 $\mu \mathrm{m}$ wide at the bulbous base, 4.5-5 $\mu \mathrm{m}$ wide at the truncate apex. Conidia apical, solitary, dry, (7-)9-16-euseptate, straight or slightly curved, obclavate, sometimes rostrate, rarely obclavate-fusiform, 52.5-145 $\times 10-15 \mu \mathrm{m}$, brown, smooth-walled; apical cell rounded, light brown, 5.5-9(-11) $\mu \mathrm{m}$ wide; basal cell obconical, frequently slightly darker than the rest of cells, 3.5-4 $\mu \mathrm{m}$ wide. Sexual morph unknown.

SPECIMEN EXAMINED: SPAIN, Castilla-La Mancha, Natural Park Alto Tajo. On dead wood. 5 May 2011. M.Hernández-Restrepo, J.Mena \& J.Guarro (holotype CBS H-21047, isotype FMR 12067). 
Only other two species of Stanjehughesia such as St. hormiscioides (Corda) Subram. and St. curviapicis (Goh \& K.D.Hyde) D.A.C.Almeida \& Gusmão (=St. hamatiella W.P.Wu) have conidia with a subhyaline or pale brown apical cell and conico-truncate basal cell usually darker than the rest as occurs in St. obclavorostrata (Subramanian 1992, Wu \& Zhuang 2005, Almeida et al. 2014).

Stanjehughesia hormiscioides, the type species of the genus, has become objected to complex taxonomic and nomenclatural problems. The current name for this species, as recognized by both Index Fungorum (http://www.indexfungorum.org/) and MycoBank (http://es.mycobank.org/) is Sporidesmium hormiscioides Corda, which would imply the establishment of a new type for Stanjehughesia Subram. Based on Ellis $(1958,1976)$ and Hughes \& Illman (1974), conidia are described and illustrated as arising from single conidiogenous cells from micronematous conidiophores. We follow Subramanian (1992) and Wu \& Zhuang (2005) including this species in Stanjehughesia.

In contrast to St. obclavorostrata, conidia of St. hormiscioides are cylindrical-fusoid to subcylindrical and larger, i.e. 65-270 × 10-17 $\mu \mathrm{m}$ (Ellis 1958, 1976; Hughes \& Illman 1974). Hughes (1958) observed that the conidia of St. hormiscioides are morphologically very variable; some specimens produced long conidia with subulate distal ends (conidia in an European collection were up to $400 \mu \mathrm{m}$ long), while in other specimens the conidia are shorter and more cylindrical with a broad blunt apex.

Stanjehughesia curviapicis is distinguished by its hamate conidia with a characteristic curved or circinate apex, which are also narrower than those of St. obclavorostrata. The conidia of a specimen of St. curviapices described as Janetia curviapices Goh \& K.D.Hyde measure $65-100 \times 5.5-7.5 \mu \mathrm{m}($ Goh $\&$ Hyde 1996) while those of the specimen described as St. hamatiella measure 70-140 × 7-8.5 $\mu \mathrm{m}$ (Wu \& Zhuang 2005).

Stanjehughesia obclavorostrata also slightly resembles St. fasciculata J.Mena, G.Delgado \& Guarro, St. fusiformis W.P.Wu, St. polypora W.P.Wu and St. ventricosa 
Marinc., M.J.Wingf. \& Crous. However, conidia of St. fasciculata are smaller (70-100 × 9$10.5 \mu \mathrm{m}$ ) and have a globose mucilaginous appendage at the apex (Mena et al. 2001, Wu \& Zhuang 2005); in St. fusiformis they are shorter and narrower (6-8-septate, $65-85 \times 7-8 \mu \mathrm{m})$ (Wu \& Zhuang 2005); conidia of St. polypora are longer (110-165 $\mu \mathrm{m}$ long) and conidial cells have a germ pore (Wu \& Zhuang 2005); while those of St. ventricosa are somewhat similar in size and septal number, but the basal cell is not darker than the rest (Marincowitz et al. 2008).

Some species described in Janetia could belong to Stanjehughesia, mainly after Goh \& Hyde (1996) who modified Ellis' original generic concept of Janetia to include species with simple conidiophores or synnemata, monoblastic or polyblastic, denticulate conidiogenous cells, and euseptate or distoseptate, and obclavate or cylindrical conidia. Among species of Janetia with a darker conidial basal cell, J. capnophila S.Hughes is comparable with St. obclavorostrata by their similar conidial morphology. However, J. capnophila is associated with sooty moulds, its conidia germinate at the apex to produce a hypha frequently anastomosing with other conidia, and several conidial cells may become conidiogenous (Hughes 1983).

\section{ACKNOWLEDGEMENTS}

This study was supported by the Spanish Ministerio de Ciencia y Tecnología, grant CGL 2011-27185.

\section{REFERENCES}

ALMEIDA, D.A.C., A.N. MILLER \& L.F.P. GUSMÃO 2014: New species and combinations of conidial fungi from the semi-arid Caatinga biome of Brazil. - Nova Hedwigia 98: 431-447. 
CASTAÑEDA-RUIZ, R.F. 2005: Metodología en el estudio de los hongos anamorfos. - In:

Anais do V Congresso Latino Americano de Micología, Brasilia: 182-183.

ELLIS, M.B. 1958: Clasterosporium and some allied Dematiaceae. Phragmosporae I. Mycol. Papers 70: 1-89.

ELLIS, M.B. 1971: Dematiaceous Hyphomycetes. - Commonwealth Mycological Institute, Kew. 608 pp.

ELLIS, M.B. 1976: More Dematiaceous Hyphomycetes. - Commonwealth Mycological Institute, Kew. 507 pp.

GOH, T.K. \& K.D. HYDE 1996: Janetia curviapicis, a new species, and an emended description of the genus. - Mycologia 88: 1014-1021.

HERNÁNDEZ-GUTIÉRREZ, A \& B.C. SUTTON 1997: Imimyces and Linkosia, two new genera segregated from Sporidesmium sensu lato, and description of Polydesmus. - Mycol. Res. 101: 201-209.

HERNÁNDEZ-RESTREPO, M., C. SILVERA-SIMÓN, J. MENA-PORTALES, A. MERCADO-SIERRA, J. GUARRO et al. 2012: Three new species and a new record of Diplococcium from plant debris in Spain. - Mycol. Progr. 11:191-199.

HUGHES, S.J. 1958: Revisiones hyphomycetum aliquot cum appendice de nominibus rejiciendis. - Can. J. Bot. 36: 727-836.

HUGHES, S.J. 1979: Relocation of species of Endophragmia auct. with notes on relevant generic names. - N. Z. J. Bot. 17: 139-188.

HUGHES, S.J. 1983: New Zealand Fungi 32. Janetia capnophila sp. nov. and some allies. N. Z. J. Bot. 21:177-182.

HUGHES S.J. \& W.I. ILLMAN 1974: Sporidesmium hormiscioides. - Fungi Canadenses 58: $1-2$. 
KIRK, P.M. 1982: New or interesting Microfungi VI. Sporidesmiella gen. nov. (Hyphomycetes). - Trans. Br. Mycol. Soc. 79: 479-489.

MARINCOWITZ, S., P.W. CROUS, J.Z. GROENEWALD \& M.J. WINGFIELD 2008: Microfungi occurring on Proteaceae in the fynbos. - CBS-KNAW Fungal Biodiversity Centre, Utrecht, The Netherlands. CBS Biodiversity Series 7: 1-166.

MATSUSHIMA, T. 1971: Microfungi of the Solomon Islands and Papua-New Guinea. Published by the author, Kobe, Japan. 78 pp.

MATSUSHIMA, T. 1975: Icones microfungorum a Matsushima lectorum. - Published by the author, Kobe, Japan. 209 pp.

MATSUSHIMA, T. 1983: Matsushima Mycological Memoirs 3: 1-90. - Published by the author, Kobe, Japan.

MENA, J., G. DELGADO, A. MERCADO, J. GENÉ, J. GUARRO et al. 2001: New or interesting hyphomycetes from the Biosphere Reserve of Sierra del Rosario, Cuba. Mycologia 93: 751-757.

RAJESHKUMAR, K.C., S.C. KAJALE, S.A. SUTAR \& S.K. SINGH 2012: Ellisembia karadkensis sp. nov. from southern Western Ghats, India. - Mycotaxon 121: 181-186.

RÉBLOVÁ, M. 1999: Studies in Chaetosphaeria sensu lato III. Umbrinosphaeria gen. nov., and Miyoshiella with Sporidesmium anamorphs. - Mycotaxon 71: 13-43.

SEIFERT, K., G. MORGAN-JONES, W. GAMS \& B. KENDRICK 2011: The genera of Hyphomycetes. - CBS-KNAW Fungal Biodiversity Centre, Utrecht, The Netherlands. CBS Biodiversity Series 9: 1-997.

SHENOY, B.D., R. JEEWON, W.P. WU, D.J. BHAT \& K.D. HYDE 2006: Ribosomal and RPB2 DNA sequence analyses suggest that Sporidesmium and morphologically similar genera are polyphyletic. - Mycol. Res. 110: 916-928. 
SHOEMAKER, R.A. \& S. HAMBLETON 2001: "Helminthosporium" asterinum, Polydesmus elegans, Imimyces, and allies. - Can. J. Bot. 79: 592-599.

SUBRAMANIAN, C.V. 1992: A reassessment of Sporidesmium (Hyphomycetes) and some related taxa. - Proc. Indian natn. Sci. Acad. Part B 58: 179-190.

SUTTON, B.C. \& C.S. HODGES 1979: Eucalyptus microfungi: Chaetophragmopsis gen. nov. and other hyphomycetes. - Nova Hedwigia 29: 593-607.

WU, W. \& W. ZHUANG 2005: Sporidesmium, Endophragmiella and related genera from China. - Fungal Diversity Press. 351 pp. Hong Kong. 